\title{
PENYULUHAN URGENSI SUMBERDAYA PESISIR DAN LAUTAN DI PULAU KEMUJAN TAMAN NASIONAL KARIMUNJAWA
}

\author{
Septa Riadi*1, Husna Purnama ${ }^{2}$, Ahirudin ${ }^{3}$, Kuswarak ${ }^{3}$ \\ Universitas Sang Bumi Ruwa Jurai \\ e-mail: *11 septa.riadi.sr@gmail.com, ${ }^{2}$ husnapurnama@ gmail.com, ${ }^{3} 1$ ardhahabi123@ gmail.com, \\ ${ }^{4}$ kuswarak23@gmail.com
}

\begin{abstract}
Abstrak
Taman Nasional Karimunjawa adalah salah satu kawasan pelestarian alam di Kabupaten Jepara, Propinsi Jawa Tengah yang memiliki ekosistem asli. Perencanaan penataan Taman Nasional Karimunjawa diharapkan dapat mendorong peran serta masyarakat dan pihak-pihak lain dalam pembangunan konservasi. Secara prinsip kriteria yang harus disepakati dalam pembagian zonasi adalah batasan tanggung jawab masing-masing sektor guna menghindari terjadinya tumpang tindih kepentingan tugas dan wewenang dengan memperhatikan daya dukung sumber daya alam yang ada. Oleh karena itu, perlu dilakukan sebuah penyuluhan mengenai pentingnya menjaga sumberdaya di Taman Nasional Karimunjawa yang diharapkan dapat bermanfaat bagi pembangunan konservasi sumberdaya alam serta sebagai acuan teknis dalam pengelolaan Taman Nasional Karimunjawa. Penyuluhan dilakukan dengan cara penyuluhan lapangan dan wawancara serta pengisian kuesioner menggunakan 3 metode yaitu Travel Cost Method, Contingent Valuation Method, dan Effect on Production. Hasil dari penyuluhan didapat bahwa Mayoritas responden antusias dalam wawancara dan juga dapat menerima masukan dan saran tim untuk menjaga kelestarian alam di Taman Nasional Karimun Jawa.
\end{abstract}

Kata kunci : Karimunjawa, Pula Kemujan, Sumberdaya, Taman Nasional

\begin{abstract}
Karimunjawa National Park is one of the nature conservation areas in Jepara Regency, Central Java Province which has a native ecosystem. Karimunjawa National Park structuring planning is expected to encourage community participation and other parties in conservation development. In principle, the criteria that must be agreed upon in the distribution of zoning are the limits of the responsibilities of each sector so that the interests of duties and authorities do not overlap while still paying attention to the carrying capacity of existing natural resources. Therefore, it is necessary to conduct education on the importance of preserving the resources in the Karimunjawa National Park which is expected to be useful for the development of natural resource conservation as well as a technical reference in the management of the Karimunjawa National Park. Extension is carried out through field counseling and interviews as well as filling out a questionnaire using 3 methods, namely the Travel Cost Method, Contingent Valuation Method, and Effect on Production. The results of the counseling showed that the majority of respondents were enthusiastic in the interviews and were also able to receive input and suggestions from the nature conservation team in the Karimun Jawa National Park.
\end{abstract}

Keywords : Karimunjawa, Kemujan Island, Resources, National Park

\section{PENDAHULUAN}

Taman Nasional Karimunjawa (TNKJ) merupakan salah satu kawasan konservasi yang ada di Indonesia, tepatnya di Kabupaten Jepara [1], Provinsi Jawa Tengah yang memiliki ekosistem asli. Taman nasional ini dikelola dengan sistem zonasi yang dapat dimanfaatkan 
untuk tujuan penelitian, ilmu pengetahuan, pendidikan, menunjang budidaya, pariwisata dan rekreasi.

Lingkungan di Karimunjawa terbagi atas lima tipe ekosistem yaitu hutan hujan tropis dataran rendah, hutan pantai, hutan mangrove, ekosistem lamun dan ekosistem terumbu karang. Dengan segala potensi yang ada di dalamnya, wilayah tersebut telah dijadikan penyangga kehidupan bagi 8.842 penduduk yang selama ini berinteraksi dengan ekosistem di sekelilingnya. Interaksi penduduk dengan ekosistem ini dinamis, namun juga memiliki nilai kerawanan. Dinamis karena wilayah ini merupakan pertemuan antara ekosistem daratan dan lautan sehingga membentuk hubungan yang sangat kompleks. Rawan karena aktivitas manusia membutuhkan ruang dan sumber daya yang mempengaruhi kualitas lingkungan di sekelilingnya.

Pembangunan Kep. Karimunjawa harus mampu mengakomodir dua hal penting, yaitu kesejahteraan masyarakat dan kelestarian lingkungan. Oleh karenanya pembangunan Karimunjawa harus memiliki manfaat terbesar untuk masyarakat. Orientasi pengembangan harus memiliki keseimbangan kepentingan antara ekonomi dan konservasi dan seluruh rangkaian proses dari pengembangan sampai dengan pembangunan melibatkan masyarakat dan stakeholder terkait.

Dalam konteks ini Kep. Karimunjawa sebagai kawasan wisata, orientasi pengembangannya harus memiliki program kegiatan dengan muatan yang seimbang antara kepentingan pariwisata dan konservasi untuk kesejahteraan masyarakat sebagai kawasan pariwisata. Karimunjawa haruslah dapat dikembangkan menjadi salah satu wilayah pertumbuhan dan menjadi produk kolektif regional, sehingga kawasan dapat dikembangkan menjadi:

1. Wilayah sebagai pusat pertumbuhan berdasarkan potensi yang dimiliki

2. Secara sengaja menciptakan integrasi fungsional berbagai pusat pertumbuhan dengan pertimbangan adanya fungsi-fungsi yang komplementer

3. Pendekatan desentralisasi dengan mengembangkan prinsip pengelolaan wilayah

Dalam aspek konservasi ada tiga kebijakan yang terkait dengan pengembangan yaitu:

1. Pemanfaatan secara lestari potensi sumber daya alam hayati dan ekosistemnya

2. Mewujudkan pengelolaan taman nasional yang relevan dengan aspek ekologis, ekonomi dan sosial masyarakat

3. Meningkatkan kerjasama pendidikan konservasi lingkungan melalui pariwisata alam

Gugusan terumbu karang di Kepulauan Karimunjawa merupakan gugusan terumbu karang tepi. Hasil survei yang dilakukan oleh 
Wildlife Conservation Society (WCS) sepanjang tahun 2003 dan 2004 menemukan 63 genera dari 15 famili karang keras berkapur (scleractinian) dan tiga genera non-scleractinian yaitu Millepora dari kelas Hydrozoa, Heliopora dan Tubipora dari kelas Anthozoa.

Ikan karang yang ditemui di perairan Karimunjawa merupakan jenis-jenis yang biasa hidup pada perairan yang cenderung tenang, dengan arus yang tidak terlalu kencang. Kondisi terumbu karang yang memiliki rataan yang luas dengan dasar perairan yang landai namun dangkal juga menyebabkan jenis-jenis ikan yang ditemui di Karimunjawa cenderung seragam. Pada perairan dangkal Karimunjawa ditemukan 43 famili ikan karang, terutama ikan-ikan yang berasosiasi erat dengan terumbu karang. Dalam satu kali penyelaman selama 60 menit, dapat ditemukan 69 sampai 141 spesies ikan karang.

Ekosistem mangrove di Karimunjawa menyebar di seluruh kepulauan dengan luasan yang berbeda-beda. Pulau-pulau yang memiliki ekosistem mangrove adalah P. Karimunjawa, P. Kemujan, P. Cemara Kecil, P. Cemara Besar, P. Krakal kecil, P. Krakal Besar, P. Merican, P. Menyawakan dan P. Sintok. Hutan mangrove terluas terdapat di P. Kemujan dan P. Karimunjawa seluas 396,90 Ha [2]. Jenis mangrove yang ditemukan sebanyak 25 spesies dari 13 famili mangrove sejati, dan sembilan spesies dari tujuh famili mangrove ikutan di dalam kawasan, serta lima spesies dari lima famili mangrove ikutan di luar Kawasan [2].
Karimunjawa memiliki pola penyebaran yang mengelompok berdasarkan kesamaan jenis atau spesies. Sugiarianto (2000) menemukan delapan spesies lamun di tiga lokasi yaitu: Pancuran, Legon Lele dan Ujung Gelam. Hasil studi awal WCS pada tahun 2003 di empat lokasi (Menjangan Besar, Menjangan Kecil, Alangalang dan Legon Nipah) ditemukan enam spesies dari empat famili [3].

Penilaian ekosistem pesisir dan laut merupakan salah satu referensi untuk dapat melakukan penilaian kehilangan jasa ekosistem yang terjadi akibat pencemaran dan ataukerusakan lingkungan hidup yang disebabkan oleh suatu aktivitas [4]. Dan oleh sebab itu, penilaian aset sumberdaya alam dan lingkungan Taman Nasional Karimun Jawa juga dapat dilakukan dengan menggunakan pendekatan yang sama, yaitu valuasi ekonomi. Valuasi ekonomi jasa ekosistem sumberdaya alam dan lingkungan Taman Nasional Karimun Jawa didekati dengan menggunakan pendekatan nilai ekonomi total jasa ekosistem berdasarkan pendekatan de Groot et al (2002) yang menyebutkan bahwa nilai total jasa.

ekosistem terdiri atas:

1. nilai ekologis (ecological value, EV1),
2. nilai sosial-budaya (socialcultural value, $\mathrm{SV})$, dan

3. nilai ekonomi (economic value, EV2).

Secara matematis [4] dapat dinotasikan
Ekosistem padang lamun di 


$$
T E V=E V 1+S V+E V 2
$$

Pemanfaatan kawasan perairan cenderung mengikuti azas akses terbuka dimana semua orang berhak memanfaatkan sumberdaya dimanapun dan kapanpun secara maksimal. Kondisi ini akan diperburuk lagi dengan pertambahan jumlah penduduk, tuntutan kualitas kehidupan masyarakat, tujuan komersial, teknologi pemanfaatan sumber daya yang semakin canggih. Pola pemanfaatan ini akan membawa dampak kerusakan sumberdaya alam.

Untuk mendorong pembangunan yang berkelanjutan perlu dilakukan penataan kawasan sesuai dengan kondisi sumberdaya alam, pola pemanfaatan dan sesuai dengan daya dukung lingkungan (carrying capacity). Upaya penataan ini merupakan bagian yang tidak terpisahkan dari perencanaan tata ruang untuk keseluruhan wilayah. Pengelolaan lingkungan wilayah pesisir, laut dan pulau-pulau kecil harus dirancang secara rasional dan bertanggungjawab sesuai dengan kemampuan daya dukungnya dengan mengutamakan sebesar-besarnya kemakmuran rakyat serta memperhatikan kelestarian fungsi dan keseimbangan lingkungan kawasan pesisir bagi pembangunan yang berkelanjutan.

Pemanfaatan kawasan juga harus berazaskan pemanfaatan secara terpadu bagi semua kepentingan sumberdaya dan berhasil guna, serasi, selaras, keadilan dan perlindungan hukum dengan tetap berpedoman pada prinsip konservasi. Untuk itu maka diperlukan keterpaduan lintas sektor, kemitraan pemerintah dengan dunia usaha dan masyarakat. Untuk mewujudkan hal tersebut maka faktor keutuhan peran sumberdaya dalam tatanan lingkungan menjadi penting untuk dilestarikan. Kesamaan arah pandangan pembangunan ini memungkinkan tercapainya keserasian dalam lingkup pekerjaan masing-masing sektor dan antar sektor terkait.

Perencanaan penataan Taman Nasional Karimunjawa diharapkan dapat mendorong peran serta masyarakat dan pihak-pihak lain dalam pembangunan konservasi. Penataan zonasi mencakup penetapan kawasan yang terbagi dalam zona inti, zona perlindungan, zona pemanfaatan dan zona lainnya sesuai dengan PP No.68 tahun 1998 tentang pembagian zonasi Taman Nasional Karimunjawa. Penetapan zona lainnya disesuaikan dengan kebutuhan pelestarian sumberdaya alam hayati dan ekosistemnya berdasarkan kriteria yang ada.

Secara prinsip kriteria yang harus disepakati dalam pembagian zonasi adalah batasan tanggung jawab masing-masing sektor guna menghindari terjadinya tumpang tindih kepentingan tugas dan wewenang dengan memperhatikan daya dukung sumber daya alam yang ada.

Beberapa teknik penilaian jasa ekosistem yang dapat digunakan untuk penilaian asset sumberdaya alam dan lingkungan Taman Nasional Karimun Jawa dan umum/banyak digunakan para valuator ekonomi sumberdaya diantaranya adalah travel cost methods (TCM), contingent valuation method (CVM), effect on 
production (EOP) dan benefit transfer method digunakan dalam rangka penilaian jasa (BTM) [5]-[11]. Hubungan nilai ekonomi total ekosistem selengkapnya dapat dilihat pada dengan benefit dan metode valuasi yang dapat Gambar 1 berikut:

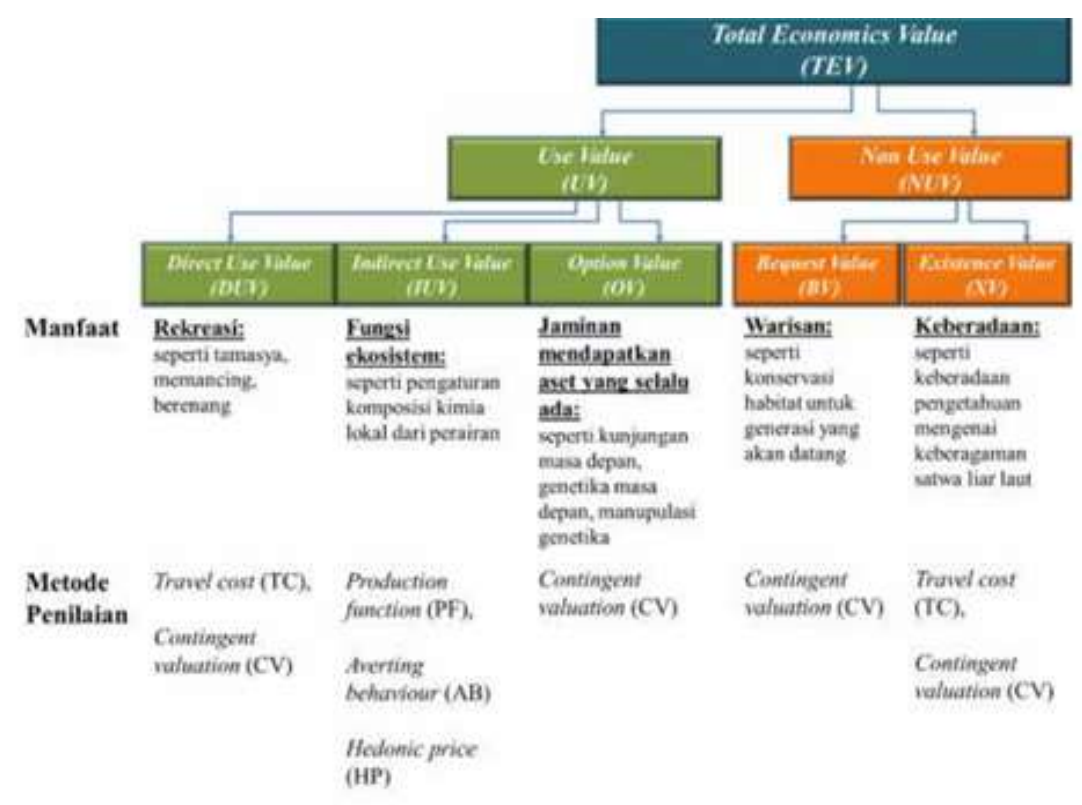

Gambar 1. Nilai Ekonomi Total, manfaat jasa ekosistem dan metode valuasinya

\section{METODE}

\subsection{Metode Yang digunakan}

\subsubsection{Penyuluhan Lapangan}

Metode ini dipilih untuk dapat menjangkau para pemilik dan pengguna sumberdaya baik nelayan, penikmat wisata dan juga anggota masyarakat yang lain yang terhubung dengan sumberdaya alam di Taman Nasional Karimun Jawa

\subsubsection{Wawancara dan Pengisian \\ Kuesioner \\ Metode ini dipilih untuk mengetahui sejauh mana kesadaran para pemilik dan pengguna sumberdaya sebelum dilakukan}

penyuluhan lapangan mengenai nilai asset sumberdaya alam dan juga bagaimana cara menjaga keberlanjutan sumberdaya alam tersebut.

Dalam kegiatan ini, metode yang digunakan dalam kegiatan ini berjumlah 3 metode, yaitu:

1. Travel Cost Method, metode ini digunakan untuk mengetahui tingkat penilaian para wisatawan terhadap sumberdaya alam

2. Congtigent Valuation Method, metode ini digunakan untuk mengetahui tingkat penilaian pemilik sumberdayaterhadap sumberdya yang ada. 
3. Effect on production, metode ini digunakan untuk mengetahui tingkat penilaian pengguna sumberdaya terhadap sumberdaya yang ada

Untuk masing-masing metode, diambil sampel dan dilakukan penyuluhan terhadap 30 orang.

\subsection{Jadwal Kegiatan}

Kegiatan Pengabdian kepada masyarakat dilaksanakan selama 3 bulan yakni bulan November 2020 s/d Januari 2021 bertempat di Dinas Lingkungan Hidup Kabupaten Jepara dan juga Pulau Kemujan Taman Nasional Karimun Jawa. Adapun rincian kegiatan sebagai berikut:

\begin{tabular}{|c|c|c|c|c|}
\hline \multirow[b]{2}{*}{ No. } & \multirow[b]{2}{*}{ Uraian Kegiatan } & \multicolumn{3}{|c|}{ Bulan } \\
\hline & & $\begin{array}{l}\text { Nov. } \\
2020\end{array}$ & $\begin{array}{l}\text { Des. } \\
2020\end{array}$ & $\begin{array}{l}\text { Jan. } \\
2021\end{array}$ \\
\hline 1. & $\begin{array}{l}\text { Penyusunan } \\
\text { Laporan }\end{array}$ & & & \\
\hline 2. & $\begin{array}{l}\text { Persiapan } \\
\text { kegiatan }\end{array}$ & & & \\
\hline 3. & $\begin{array}{l}\text { Pelaksanaan } \\
\text { Kegiatan }\end{array}$ & & & \\
\hline 4. & Pelaporan & & & \\
\hline
\end{tabular}

Keterangan :

a. Penyusunan proposal kegiatan dilakukan sebagai tahap pertama pengajuan program pengabdian masyarakat

b. Persiapan penyuluhan yang dilakukan meliputi pengumpulan materi- materi penyuluhan. c. Penyuluhan yang akan dilakukan meliputi kegiatan pemaparan materi kepada instansi terkait baik Dinas Lingkungan Hidup Provinsi dan Juga Dinas Lingkungan Hidup Kabupaten serta wawancara kepada para pemilik dan pengguna sumberdaya di Taman Nasional Karimun Jawa

d. Pelaporan hasil kegiatan akan dilakukan sebagai bentuk pertanggungjawaban atas kegiatan.

\section{HASIL DAN PEMBAHASAN}

\subsection{Laporan Kegiatan}

Kegiatan berlangsung dalam beberapa tahapan, tahapan pertama adalah persiapan kegiatan untuk berkordinasi dengan berbagai pihak yang terkait. Mengingat sangat banyaknya pihak-pihak yang terkait dalam kegiatan ini tahap persiapan ini harus direncanakan dengan matang. Pada hari kegiatan, seluruh team berkumpul di Bandar Udara Soekarno-Hatta Jakarta untuk selanjutnya melakukan penerbangan ke kota Semarang, yang dilanjutkan dengan perjalanan darat ke kota Jepara untuk melakukan kordinasi bersama Dinas Lingkungan Hidup Kabupaten Jepara. Selanjutnya perjalanan laut dilanjutkan ke pulau Karimunjawa dan disambut oleh tim dari Balai Taman Nasional Karimunjawa. 
Empat hari berikutnya kegiatan dilakukan penyuluhan kepada masyarakat dan dengan melakukan wawancara dan pengunjung taman wisata Karimunjawa.
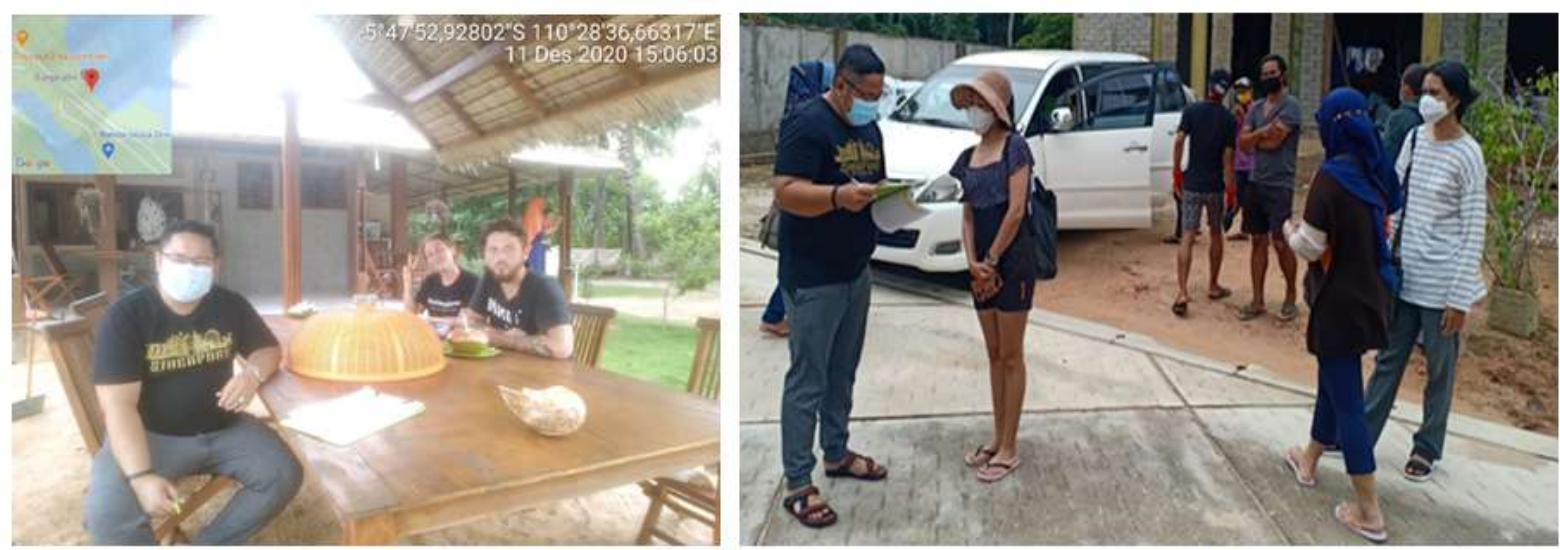

Gambar 2. Wawancara dan penyuluhan kepada wisatawan lokal dan mancanegara menggunakan pendekatan Travel Cost Method

Kegiatan wawancara menggunakan tiga macam pendekatan yaitu metode Travel Cost Method, metode ini digunakan untuk mengatahui besaran biaya yang dikeluarkan oleh para wisatawan untuk mengunjungi Taman Nasional Karimunjawa. Wisatawan yang mendatangi Taman Nasional Karimun Jawa sangatlah beragam, baik wisatawan lokal dari wilayah Jawa, Sumatera hingga Kalimantan hingga wisatawan asing yang berasal dari Jerman, Rusia dan Juga China. Biaya yang wisatawan keluarkan bervariasi dengan total antar Rp 2.000.000 hingga Rp.24.000.000, hal ini menunjukan bahwa nilai ekonomi Taman Nasional Karimun Jawa sangat potensial. Selama wawancara juga, tim melakukan penyuluhan tentang bagaimana menjaga sumberdaya pesisir dan laut terutama karang yang sangat mudah rusak dengan masa pemulihan yang sangat panjang, hingga puluhan tahun. Dari hasil wawancara didapatkan data bahwa mayoritas wisatawan yang berkunjung ke Taman Nasional Karimunjawa berpendidikan yang tinggi mayoritas sarjana dan pascasrjana dengan pendapatan menengah keatas. Hal ini berimbas kepada tingginya kesadaran mereka untuk menjaga kelestarian alam. Secara umum, mereka mengetahui fungsi-fungsi ekologi alam baik nilai yang dapat digunakan langsung maupun tidak langsung. Gambaran tingkat kesadaran wisatawan sebelum dan sesudah penyuluhan terdapat dalam gambar 3.

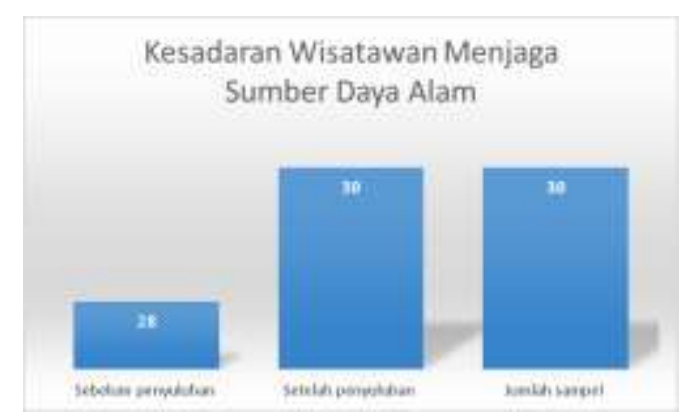

Gambar 3. Perubahan tingkat kesadaran wisatawan setelah penyuluhan

Pendekatan kedua adalah metode effect on production (EOP). Pendekatan ini digunakan 
untuk mengukur penurunan tingkat pendapatan nelayan akibat kerusakan lingkunga hidup. Dalam kegiatan ini 30 nelayan diwawancara mengenai modal, biaya perawatan dan pendapatan yang mereka dapatkan. Sebagian besar nelayan di Taman Nasional Karimunjawa berpendidikan rendah, yaitu SD hingga SMP, namun mereka telah sadar akan pentingnya menjaga kelestarian lingkungan karena berpengaruh terhadap pendapatan mereka sebagai nelayan. Tim juga melakukan penyuluhan untuk tidak menggunkan alat tangkap yang merusak lingkungan terutama terumbu karang seperti tidak menggunakan racun, bom dan alat tangkap perusak seperti pukat tarik dan hela yang menggunkan pemberat dasar. Hasil perubahan tingkat kesadaran nelayan setelah dilakukan penyuluhan dapat dilihat di gambar 5 .

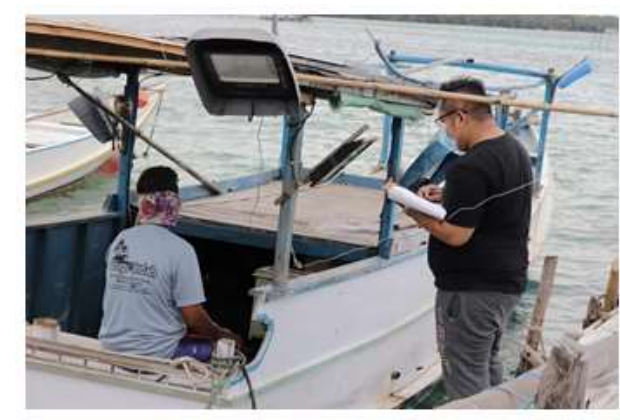

Gambar 4. Wawancara dan penyuluhan kepada nelayan sebagi pengguna sumberdaya dengan

Efect On Production Method (EOP)

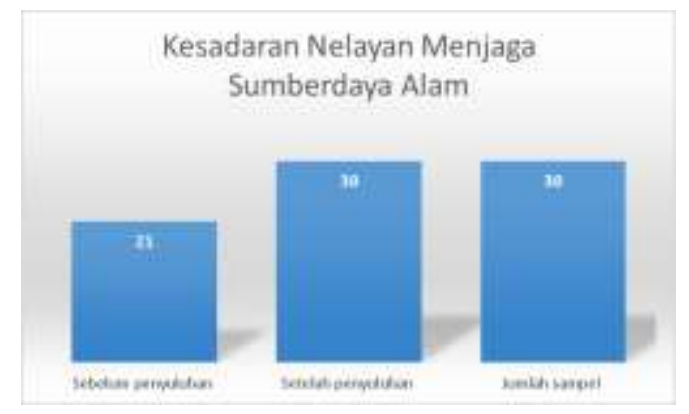

Gambar 5. Perubahan Tingkat Kesadaran

Nelayan Setelah Penyuluhan

Pendekatan ketiga adalah Contingent Valuation Method (CVM), pendekatan ini digunakan untuk mengetahui penilaian masyarakat pemilik sumberdaya terhadap sumberdaya yang mereka miliki. 30 masyarakat diwawancarai untuk mengetahui penilaian mereka terhadap sumberdaya yang mereka miliki. Mayoritas responden yang diwawancara berpendidikan rendah yaitu sekolah dasar. Akibat dari rendahnya pendidikan ini, mayoritas responden tidak memiliki pengetahuan yang mencukupi tentang pentingnya menjaga sumberdaya alam. Mayoritas responden hanya mengetahui nilai ekonomi langsung dari sumberdaya seperti fungsi mangrove bagi mereka hanya untuk kayu bakar tanpa mengetahui bahwa mangrove memiliki fungsi lain yang tidak kalah penting seperti menjaga lahan dari abrasi dan sebagai penjaga keanekaragaman hayati dan juga nilai-nilai ekonomi tidak langsung yang lain. Begitupun dengan karang, bagi mereka tidak ada nilai penting terumbu karang karena tidak bisa digunkan secara langsung. Mereka tidak 
memahami fungsi lain karang yang bernilai sangat tinggi seperti sebagai tempat memijah dan pembesaran ikan bernilai ekonomi tinggi, sebagai pemecah ombak, dan yang terpenting dapat menjadi daya tarik bagi wisata selam yang benilai ekonomi tinggi. oleh karenanya tim memberikan penyuluhan tentang pentingnya menjaga sumberdaya yang memiliki nilai ekonomi tinggi baik secara langsung maupun tidak langsung. Hasil perubahan tingkat kesadaran masyarakat setelah dilakukan penyuluhan dapat dilihat di gambar 7 .

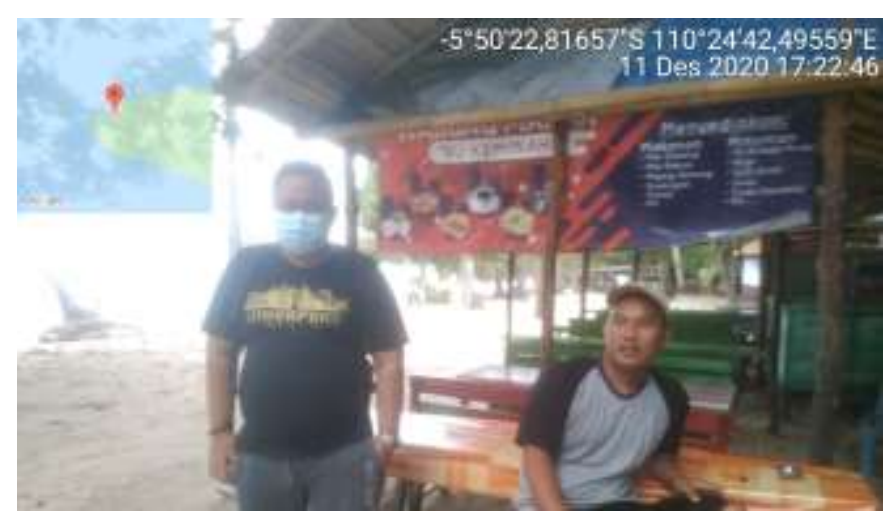

Gambar 6. Wawancara dan penyuluhan kepada pemilik sumberdaya dengan pendekatan Contingent Valuation Method (CVM)

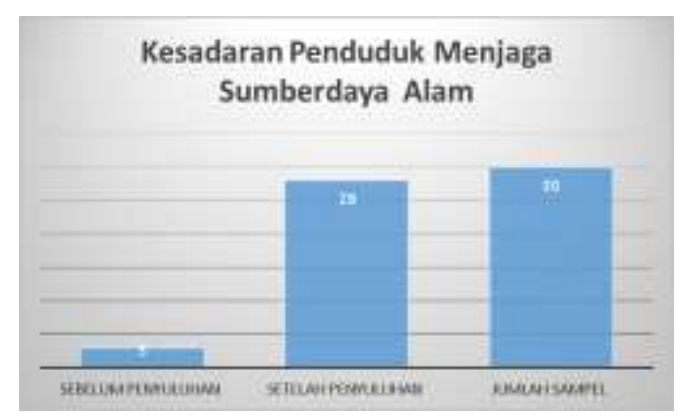

Gambar 7. Perubahan Tingkat Kesadaran Penduduk Setelah Penyuluhan

\subsection{Evaluasi Kegiatan}

Secara umum kegiatan ini sudah berjalan dengan sangat baik, pihak Balai Taman Nasional Karimunjawa dengan maksimal membantu tim dalam melaksanakan kegiatan ini dengan memberikan akomodasi dan transportasi yang memadai. Namun karena kegiatan ini diadakan ditengah pandemi, banyak kendala yang dialami, terutama jumlah wisatawan yang sedang menurun di wilayah Taman Nasional Karimunjawa.

\section{SIMPULAN}

Setelah melakukan kegiatan $\mathrm{PkM}$ ini disimpulkan bahwa mayoritas responden antusias dalam wawancara dan juga dapat menerima masukan dan saran tim untuk menjaga kelestrarian alam di Taman Nasional Karimun Jawa.

\section{SARAN}

Kegiatan ini sebaiknya dilaksanakan secara rutin di wilayah-wilayah yang memiliki sumberdaya pesisir dan lautan yang bernilai tinggi agar dapat mengontrol kerusakan sumberdaya alam lebih lanjut dan memperbaiki kerusakan yang terjadi.

UCAPAN TERIMA KASIH 
Penulis mengucapkan terima kasih kepada Kementerian Lingkungan Hidup dan Kehutanan yang telah memberi dukungan moral dan dana terhadap program pengabdian masyarakat ini ini.

\section{DAFTAR PUSTAKA}

[1] N. Pangaribuan, I. Winarni, M. Toha, and S. Utami, Optimalisasi Peran Sains \& Teknologi untuk Mewujudkan Smart City, vol. 44, no. 8 . banten: Universitas Terbuka, 2017.

[2] BTNKJ, "Inventarisasi dan Penyebaran Mangrove di Taman nasional Karimun Jawa," Semarang, 2002.

[3] Balai Taman Nasional Karimunjawa, "Penataan Zonasi Taman Nasional Karimunjawa, Kabupaten Jepara, Provinsi Jawa Tengah.," no. 2, p. 63, 2004, [Online]. Available: http://www.tnkarimunjawa.com.

[4] Mahipal and Y. Wahidin, "Kajian hukum penerapan penilaian lingkungan hidup di wilayah pesisir Indonesia," J. Cendekia Ihya, vol. 2, no. 1, pp. 43-55, 2019.

[5] R. Costanza et al., "The value of the world's ecosystem services and natural capital," Nature, vol. 387, no. 6630, pp. 253-260, 1997, doi: 10.1038/387253a0.

[6] R. S. de Groot, M. A. Wilson, and R. M. J. Boumans, "A Typology for the
Classification, Description and Valuation of Ecosystem Functions, Goods and Services," Ecol. Econ., vol. 41, pp. 393408, 2002.

[7] R. de Groot et al., "Global estimates of the value of ecosystems and their services in monetary units," Ecosyst. Serv., vol. 1, no. 1, pp. 50-61, 2012, doi: 10.1016/j.ecoser.2012.07.005.

[8] L. Adrianto, Pengantar Penilaian Ekonomi Sumberdaya Pesisir dan Laut. Bogor: PKSPL IPB Bogor, 2006.

[9] Y. Wahyudin, "Kajian Keterkaitan Sistem Sosial-Ekologi Lamun dalam Meningkatkan Nilai Ekonomi Sumberdaya Ikan di Wilayah Pesisir Pulau Bintan," Bogor Agricultural University, 2018.

[10] R. Costanza et al., "Changes in the global value of ecosystem services," Glob. Environ. Chang., vol. 26, no. 1, pp. 152158, 2014, doi: 10.1016/j.gloenvcha.2014.04.002.

[11] L. Adrianto, Y. Wahyudin, I. wayan Nurjaya, M. Krisanti, Yonvitner, and A. Trihandoyo, "Valuasi Ekonomi Kerusakan Ekosistem Sumberdaya Pesisir dan Laut Kota Bontang," Work. Pap. PKSPL, vol. 7, no. 4, 2016. 